\title{
The Question of the Genetic Identity of Individuals between National Law and the European Court of Human Rights
}

\author{
Gatt L* \\ Department of Private law, University of Naples, Italy
}

*Corresponding author: Lucilla Gatt, Director of the Research Centre in European Private Law (ReCEPL), University of Naples Suor Orsola Benincasa, Italy, Email: lucilla.gatt@unisob. na.it

\section{Investigation Paper}

Volume 3 Issue 3

Received Date: August 21, 2020

Published Date: September 07, 2020

DOI: $10.23880 /$ abca-16000130

\section{Abstract}

This work is focused on minors without genetic identity in (old and) new family models. In Europe, this situation generates hard conflicts between Internal Public Order and the so-called International Public Order . The last one is mostly identified with the case law of th European Court of Human Rights.

\section{Introduction}

In Europe in the last fifteen years, the cases of the diversity of the genetic heritage of the child compared to that of their legal parents have increased exponentially ${ }^{1}$. In Italy this is due to the judgments of the Italian Constitutional Court of 2014 which have made lawful the use of medically assisted heterologous procreation techniques in our system. Furthermore, it is to consider the law on civil unions of May 2016 which has legitimized the same-sex couples. An important role have played also the recent judgments of local Courts (Court of Appeal of Trento and Court of Minors of Florence of March 2017) and, above all, the case law of the Italian High Court which has recognized, in various situations, the relationship of filiation between parents of the same sex and minors whose genetic heritage, in the most of the cases, is not shared even by one of the legal parents.

The word "parents", in these cases, is accompanied by the adjective "social" which underlines and highlights the peculiarity of the relationship connecting certain adults with certain minors of whom the former intend to take responsibility. The reasons for this situation are lot of. We mention a few: progressive widespread diffusion and refinement of the MAP techniques that allow highly

1 I.A. Caggiano, Veridicità della filiazione ed errore nella procreazione assistita. Un rapporto possibile tra interpretazione della legge e studi empirici, (Pacini editore 2018) p. 1-268. sophisticated interventions of "mixing" of gametes and embryo implants in subjects other than those from which the gametes themselves come; progressive legitimation of the aforementioned MAP techniques in many countries around the world and in Europe, in particular; legitimation of the practice of surrogacy and its progressive and considerable diffusion: the combination of the MAP and surrogacy ${ }^{2}$. These phenomena that can be defined, in a broad sense, as examples of the application of the more advanced technologies for managing the procreation process of human beings, are contemporaries to the progressive advancement, in all European and non-European countries, of the rights of same-sex couples, culminating in Italy, with the recognition of the union between partners of the same sex as a legally relevant social nucleus on a personal and patrimonial level exactly like the not same-sex couple.

This recognition is complemented by the need to establish legally relevant relationships of filiation between the members of the same-sex couple and the (genetic) child of at least one of them or the child of none of them got with the application of the aforementioned MAP techniques and/ or surrogacy. Just in very few cases, a same-sex couple has asked to adopt already born children with whom they have not had any relationship before.

2 Grimaldi $\mathrm{P}$, 'Gli accordi di maternità surrogata tra autodeterminazione sulle scelte procreative, autonomia privata e best interest of the child' (2017) 5-6 Familia p. 323-338. 
In Italy, the legislator, already late in satisfying the first need of homologation between same-sex and non-same-sex couples, has a lot of difficulties with the second need and thus it formulates incomplete and ambiguous norms.

Judges, on the other hand, oppressed by the prohibition of non-liquet, find themselves having to manage and first of all to satisfy requests of the registration of birth certificates already registered abroad and that establish a legally relevant relationship of filiation with two mothers and/or two fathers; requests of the recognition of foreign judgments that validate the adoption by the same-sex partner of the genetic child of the other partner; requests of the recognition of foreign judgments that validate relationships of filiation between heterosexual or same-sex couples and children born by surrogate motherhood, which at present appears to be a criminal case in the Italian legal system according to law no. 40 of 2004 . All this takes place mainly by resorting to the so-called International Public Order. That is to say a set magmatic of rules and principles that can be enucleated by the reading of International Treaties on minors and, above all, of the sentences of the supranational courts. In particular, a very important role and often also a "pre-judicial" consideration is attributed to the aka European Court of Human Rights (ECHR).

It would allow almost magically overcoming the rules of internal public order, favouring a sort of "legal conformism" among legal systems without historical precedents (or maybe yes?). In the meantime, the minor and his/her best interest in his/her own identity, first of all, the genetic one and, among other things, also mentioned in the International Treaties are overwhelmed by completely different kind of needs, referring to completely different subjects who painfully - are precisely those who claim to want to take care of it. In times when even the right to one's genetic identity in the form on the right to know one's origins appears worthy of attention in the Italian legislative context, the hope is that of major prudence on the part of National judges in embracing the trends of the International Public Order and "legal conformism". This prudence should be functional to the deterrence of procreative practices generating minors without genetic identity. This kind of identity is essential for a human being as evidenced by the frequent searches of genetic parents made by adopting children. But close to the problem of identity is, on closer inspection, the other and serious problem of the effective recognition of a real legal subjectivity of the human embryo ${ }^{3}$. The traumatic impact of the MAP techniques in the area of the legal subjectivity of the human being forcefully emerges when attention is

\footnotetext{
3 In the National Committee of Bioethics, Statute and Identity of the human embryo that was held on June 22, 1996, it was discussed if the human embryo could be considered a human individual.
}

focused on the existence of abandoned supernumerary cryopreserved embryos $^{4}$ (Italian Health Minister decr. 4 August 2004) beyond and despite the prohibitions and regulatory limits (Article 14, Italian Law No. 40 of 2004) How can we not ask ourselves, in fact, about the legal nature of the embryo: subject or object of law? It would appear to comply with art. 1, Italian Law n. 194 of 1978 and with all the provisions of the Italian law on MAP, defining the embryo as a subject of law but then why we ask ourselves what its destiny might be if it found itself in a state of abandonment pursuant to the aforementioned health ministerial decree? The answer to this last question has to be unique if one does not want to irremediably deny the legal subjectivity of the human embryo: this is a "minor" in a state of abandonment susceptible of being adopted (by implantation in the uterus of a non-genetic mother $)^{6}$. No other proposal if not this one appears to conform to the general principles of public order of the Italian legal system as well as it seems to us to those of European public order. The national and European public order cannot definitively and irremediably put the embryo, (i.d. the human life already formed and in progress) , at the second place respect of the research activity which, even if animated by noble objectives, would have the inevitable outcome of the death of the embryo, perhaps as a result of unimaginable suffering. All that remains is to conclude by quoting who, in dramatic epochs of humanity history, had long reflected on the relationship between ethics ${ }^{7}$ and technology, focusing clearly on the problem of the limit [of human action]: " Handeln Sie so, dass die Konsequenzen Ihres Handelns mit dem Überleben eines authentischen menschlichen Lebens auf der Erdevereinbar sind [Act so that the consequences of your action are compatible with the survival of an authentic human life on earth] ${ }^{8}$.
4 Romano L, 'Embrioni crioconservati quale futuro?' (2012) p. 1-5. F.S. Porcelli, 'Sulla restituzione degli embrioni soprannumerari crioconservati' (2017) 1 Nuovo diritto civile 183,199.

5 Nicolussi A, 'Legittimità e significato giuridico dell'adozione di embrioni' (2012) 62 Scienza e vita p. 22, 23.

6 Nicolussi A, 'Si può umanizzare la procreazione medicalmente assistita?' in In margine al Sinodo 2014. Riflessioni in punto di diritto su matrimonio e famiglia, (Cacucci editore, 2014).

7 Battaglia L, 'Ragionare sui valori. Una "modesta proposta" sugli embrioni soprannumerari in tecnica e procreazione, desideri, diritti e nuove responsabilità. A margine della legge n. 40 del 2004', in M.G. Furnari (Rubbettino, 2005) 43.

8 Hans Jonas, Das Prinzip Verantwortung. Versuch einer Ethik für die technologische Zivilisation, (Frankfurt M. 1979). 